\title{
KINERJA BURSA KERJA KHUSUS (BKK) SMK NEGERI BIDANG KEAHLIAN TEKNOLOGI DAN REKAYASA DI KABUPATEN SLEMAN
}

\author{
Nirmala Adhi Yoga Pambayun \\ Pendidikan Teknologi dan Kejuruan Universitas Negeri Yogyakarta \\ n_adhiyoga_p@yahoo.com \\ Wagiran \\ Pendidikan Teknologi dan Kejuruan Universitas Negeri Yogyakarta \\ maswagiran@yahoo.com
}

\begin{abstract}
Abstrak
Penelitian ini bertujuan untuk mengevaluasi kinerja Bursa Kerja Khusus (BKK) SMK Negeri Bidang Keahlian Teknologi dan Rekayasa di Kabupaten Sleman ditinjau dari dimensi input, proses dan output. Penelitian ini merupakan penelitian evaluasi dengan model discrepancy. Responden pada penelitian ini adalah pengurus BKK dan siswa tingkat akhir (kelas XII atau XIII) di SMK Negeri Bidang Keahlian Teknologi dan Rekayasa di Kabupaten Sleman yang terdiri dari SMKN 2 Depok, SMKN 1 Seyegan, dan SMKN 1 Cangkringan. Penarikan sampel dilakukan pada responden siswa dengan teknik proportional random sampling. Data dikumpulkan dengan menggunakan inventori, lembar observasi, lembar dokumentasi dan wawancara. Pengujian validitas instrumen menggunakan validitas isi dengan penilaian dari ahli (expert judgement). Hasil penelitian ini menunjukkan bahwa kinerja BKK SMK Negeri Bidang Keahlian Teknologi dan Rekayasa baik ditinjau dari dimensi input, proses dan output secara umum masih masuk dalam kategori rendah.
\end{abstract}

Kata kunci: Kinerja, Bursa Kerja Khusus (BKK), Input, Proses, Output

\section{THE PERFORMANCE OF CAREER CENTER IN STATE VOCATIONAL HIGH SCHOOL TECHNOLOGY AND ENGINEER EXPERTISE SECTOR IN SLEMAN REGENCY}

\begin{abstract}
This study aims to evaluate the performance of Career Center in State Vocational High School Technology and Engineer Expertise Sector Sleman Regency in terms of input, process and output dimension. This study was evaluation research with discrepancy model. Respondent in this study were the Career Center administrators and the latest grade students (class XII or XIII) in State Vocational High School Technology and Engineer Expertise Sector in Sleman Regency which consist of SMKN 2 Depok, SMKN 1 Seyegan, dan SMKN 1 Cangkringan. Sampling technique for students used proportional random sampling. Data was collected with inventory, observation sheets, documentation sheets and interview. The result of this study show that, in general the performance of Career Center in State Vocational High School Technology and Engineer Expertise Sector in Sleman Regency in input, process, and output dimension is included into low category.
\end{abstract}

Keywords: Performance, Career Center, Input, Process, Output 


\section{PENDAHULUAN}

Pendidikan menengah yang sebelumnya lebih berorientasi pada Sekolah Menengah Atas (SMA) sekarang mulai diubah ke Sekolah Menengah Kejuruan (SMK). Hal ini dibuktikan dengan upaya pemerintah untuk mengubah perbandingan proporsi jumlah SMA dengan SMK menjadi 30:70. Sudira (2012, p.38) menyatakan perubahan proporsi tersebut memiliki tujuan salah satunya adalah dengan pengembangan SMK, diharapkan dapat meningkatkan daya saing SDM di Indonesia dan terjadinya penurunan jumlah pengangguran.

Tujuan memperbanyak SMK untuk mengurangi dan menekan angka pengangguran masih belum sesuai dengan yang diharapkan. Hal ini dapat dilihat dari jumlah pengangguran lulusan SMK yang saat ini masih besar jumlahnya. Jumlah pengangguran terbuka dari lulusan SMK di Daerah Istimewa Yogyakarta (DIY) berdasarkan data survei Badan Pusat Statistik (BPS) bulan Agustus tahun 2012 dapat dilihat pada tabel di bawah.

Tabel 1. Jumlah Pengangguran Terbuka di DIY

\begin{tabular}{lcc}
\hline \multicolumn{1}{c}{ Kab/Kota } & $\begin{array}{c}\text { SMA/ } \\
\text { MA }\end{array}$ & $\begin{array}{c}\text { SMK/ } \\
\text { MAK }\end{array}$ \\
\hline Kab. Kulon Progo & 3642 & 2547 \\
Kab. Bantul & 2582 & 6352 \\
Kab. Gunung Kidul & 810 & 4255 \\
Kab. Sleman & 7031 & 8622 \\
Kota Yogyakarta & 2083 & 2405 \\
\hline \multicolumn{3}{l}{ Jumlah } \\
\multicolumn{2}{l}{ Sumber: pusdatinaker.balitfo.depnakertrans.go.id }
\end{tabular}

Berdasarkan data tersebut, dapat diketahui bahwa Kab. Sleman memiliki jumlah pengangguran terbuka dari lulusan SMK yang paling tinggi. Hal ini tentunya menimbulkan pertanyaan besar karena lulusan SMK yang sudah dibekali keterampilan tertentu dan hampir semua SMK di Kab. Sleman sudah memiliki Bursa Kerja Khusus (BKK) yang berperan dalam mengarahkan dan menyalurkan lulusannya ke dunia kerja. Namun jumlah penganggurannya masih tinggi bahkan lebih tinggi jika dibandingkan dengan lulusan SMA.

Fakta mengenai jumlah pengangguran di SMK yang masih tinggi membuktikan bahwa
SMK tidak akan efektif menekan angka pengangguran apabila hanya mencetak lulusan yang siap kerja saja. Perlu adanya optimalisasi kinerja BKK yang berperan dalam pemasaran dan penyaluran lulusan, atau dalam hal ini dapat dikatakan sebagai jembatan antara lapangan pekerjaan (Dunia Usaha/Dunia Industri) dengan pencari kerja (siswa atau lulusan SMK).

Kinerja BKK dari setiap SMK akan mempengaruhi keterserapan lulusannya ke dunia kerja yang relevan. BKK yang memiliki kinerja yang baik akan dapat melaksanakan programprogram yang menjadi kewajiban dan program lain yang telah direncanakan, memiliki relasi dengan perusahaan atau industri yang banyak sehingga tempat penyaluran lulusannya menjadi lebih luas dan dapat mengurangi masa tunggu lulusan untuk mendapatkan pekerjaan. Selain itu dapat memberikan bimbingan karir dengan baik kepada siswa maupun lulusannya, sehingga mereka dapat memilih dan memiliki pengetahuan mengenai karir serta lebih siap untuk memasuki dunia bekerja. Berdasarkan hal tersebut, peran dan tugas dari BKK tidak dapat dipandang sebelah mata atau dipandang mudah. Perlu adanya dukungan dari banyak pihak dan sekolah baik itu pejabat yang berwenang maupun guru untuk dapat mensukseskan dan mencapai tujuan yang telah dirumuskan oleh BKK.

Berdasarkan uraian di atas, peran BKK sangatlah penting dalam menunjang usaha untuk meningkatkan keterserapan lulusan SMK ke dunia kerja, namun pada kenyataannya terdapat indikasi bahwa BKK belum berjalan sesuai dengan operasional yang seharusnya. Berdasarkan kegiatan pra survei, ternyata pengurus BKK SMK di Kab. Sleman yang aktif hanya berjumlah satu atau dua orang, padahal sesuai dengan petunjuk teknis BKK jumlahnya adalah 6 orang. Selain itu dari sisi pemanfaatan teknologi informasi, belum semua dimanfaatkan dengan maksimal seperti penggunaan website, pemanfaatan jejaring sosial dan lainnya. Apabila dimanfaatkan dengan baik maka hal ini dapat menunjang kegiatan BKK terutama untuk membantu memberikan informasi kepada lulusan mengenai lowongan pekerjaan yang ada, melakukan penelusuran lulusan, meng- 
umpulkan informasi lowongan pekerjaan dan kegiatan lainnya.

Hasil wawancara dengan kepala bagian penempatan tenaga kerja Disnakertrans DIY yang merupakan pembina dan pemberi pelatihan kepada pengurus BKK, disebutkan bahwa sering terjadi BKK SMK tidak melaporkan jumlah angkatan kerja dan yang sudah ditempatkan atau disalurkan. Padahal ini merupakan kewajiban dari BKK dan akan mendapatkan sanksi dan peringatan apabila tidak dilaksanakan. Selain itu, belum semua petugas BKK mengetahui bagaimana pelaksanaan bimbingan jabatan atau bimbingan karir dan mekanisme antar kerja.

Kinerja BKK yang sesungguhnya perlu diketahui sehingga dapat digunakan sebagai acuan untuk menentukan langkah dalam meningkatkan keterserapan lulusan SMK ke dunia kerja dan menentukan solusi dalam mengatasi pengangguran. Namun sampai saat ini belum terdapat data yang akurat mengenai kinerja BKK, dan bahkan belum terdapat instrumen yang dapat digunakan untuk menilai kinerja BKK khususnya di Kabupaten Sleman. Padahal untuk mendapatkan kinerja yang baik suatu lembaga atau organisasi perlu dilakukan evaluasi secara periodik untuk dapat melakukan perbaikan dan dapat meningkatkan kinerjanya. Oleh karena itu penting untuk dilakukan penelitian mengenai kinerja BKK di SMK.

\section{Bursa Kerja Khusus (BKK)}

Bursa kerja khusus (BKK) merupakan lembaga yang menjalankan fungsi penempatan untuk mempertemukan antara pencari kerja dan pengguna tenaga kerja yang terdapat di Satuan Pendidikan Menengah, di Satuan Pendidikan Tinggi dan di Lembaga Pelatihan Kerja (Depnakertrans RI, 2004, p.4). Penyediaan layanan penyaluran atau penempatan kerja lulusan, sangat penting dalam sekolah kejuruan. Organisasi Perburuhan Internasional (2007, p.45) menyatakan, "upaya memperkuat layanan lapangan kerja dianggap sebagai instumen penting dalam menangani masalah pengangguran kaum muda di pasar tenaga kerja”. Hal ini sejalan dengan kebutuhan siswa di pendidikan kejuruan khususnya di SMK, karena orientasi utama dari lulusan SMK setelah lulus adalah langsung bekerja.
Pentingnya lembaga penyalur tenaga kerja atau apabila di SMK adalah BKK, juga disampaikan oleh Ferguson (2007, p.37) yaitu "An active placement office can be a critical asset in transitioning into an occupation after completing training". Berdasarkan pendapat tersebut, placement office harus aktif sehingga dapat menjadi aset yang penting dalam menyiapkan siswa pada masa transisi ke dunia kerja setelah lulus. Oleh karena itu tugas dari placement office tidak hanya bertugas menempatkan saja, akan tetapi juga memberikan bimbingan dan penyuluhan karir sehingga siswa menjadi lebih siap dalam memasuki dunia kerja. Kerka (2006, p.4) mengungkapkan bahwa "highquality career and technical education (CTE) programs prepare students for occupations and careers in demand". Pernyataan tersebut mengandung makna bahwa untuk menyiapkan siswa untuk pekerjaan dan karir yang dibutuhkan perlu adanya kombinasi antara pendidikan teknik dengan pendidikan karir yang baik.

Secara eksplisit tujuan dari BKK yang disampaikan oleh Dinas Pendidikan Jawa Tengah (2010, p.4) adalah sebagai berikut, "(1) Mempertemukan tamatan SMK dengan DU/DI; (2) Memberikan peluang saling berinteraksi antara tamatan SMK dan DU/DI untuk menawarkan kompetensi yang dimiliki; (3) Meningkatkan hubungan kerjasama SMK dengan DU/DI melalui pendekatan personil pengelola SMK dengan perwakilan industri; (4) Meningkatkan wawasan tamatan SMK tentang peluang kerja di DU/DI, sehingga tamatan dapat memilih peluang kerja sesuai kompetensinya; (5) Terjadinya proses rekrutmen sesuai dengan formasi kerja dan kompetensi yang dibutuhkan; (6) Terserapnya tamatan ke dunia kerja.

Dalam pelaksanaannya, BKK memiliki tugas-tugas yang harus dilaksanakan berdasarkan perjanjian kerjasama antara Depdikbud dan Depnaker No. 076/U/1993 dan Kep-215/ MEN/1993 dalam Dinas Pendidikan Provinsi Jawa Tengah (2010, p.6), disebutkan bahwa penyelenggaraan bursa kerja bertujuan agar dapat memberikan bimbingan pemilihan karir, pelayanan antar kerja, perencanaan tenaga kerja, informasi pasar kerja dan analisis jabatan.

Berdasarkan perjanjian tersebut salah satu tugas BKK ini adalah melaksanakan me- 
kanisme antar kerja. "Antar kerja adalah suatu mekanisme pelayanan kepada pencari kerja untuk memperoleh pekerjaan yang sesuai dengan bakat, minat dan kemampuannya, serta pelayanan kepada pengguna tenaga kerja untuk memperoleh tenaga kerja yang sesuai dengan kebutuhan"(Depnakertrans RI, 2004, p.4).

Berikut merupakan rincian mekanisme antar kerja yang harus dilaksanakan oleh BKK berdasarkan keputusan direktur jenderal pembinaan dan penempatan tenaga kerja dalam negeri No. KEP-131/DPPTKDN/XI/2004 (Depnakertrans RI, 2004, p.9) meliputi: (1) Pendaftaran dan pendataan pencari kerja yang telah menyelesaikan pendidikan atau pelatihannya; (2) Pendataan lowongan kesempatan kerja; (3) Pemberian bimbingan kepada pencari kerja lulusannya untuk mengetahui bakat, minat dan kemampuannya sesuai kebutuhan pengguna tenaga kerja atau untuk berusaha mandiri; (4) Penawaran kepada pengguna tenaga kerja mengenai persediaan tenaga kerja; (5) Pelaksanaan verifikasi sebagai tindak lanjut dari pengiriman dan penempatan yang telah dilakukan; (6) Pelaksanaan kegiatan pameran bursa kerja (Job Fair) dan kegiatan lainnya.

Berdasarkan mekanisme antar kerja tersebut dapat diketahui bahwa BKK tidak hanya sekedar memberikan informasi mengenai lowongan pekerjaan yang ada kepada lulusan. Akan tetapi juga melakukan pendataan terhadap angkatan kerja dari lulusan, dan memberikan penawaran kepada pihak yang memiliki lowongan pekerjaan sehingga tidak hanya pasif untuk menerima adanya laporan lowongan pekerjaan dari pihak luar. Hal ini sangat penting karena aktifnya lembaga penyalur tenaga kerja ternyata juga dapat meningkatkan kepercayaan dunia kerja untuk juga aktif memberikan informasi mengenai lowongan pekerjaan yang ada (US Fed News Service, 2008).

Selain hal di atas, BKK juga memiliki kewajiban memberikan bimbingan kepada lulusan sehingga dapat memperoleh pekerjaan yang sesuai dengan minat, bakat dan kompetensi yang dimiliki. Hal ini penting karena ini merupakan salah satu dari program pemberian bimbingan karir kepada siswa. Bimbingan karir menurut Ferguson (2008, p.4), merupakan "suatu pendekatan yang sistematis untuk pengembangan karir, di mana bimbingan karir memfasilitasi pengarahan diri sendiri dengan memberikan informasi dan mendorong keterampilan pengembangan karir".

Bimbingan karir yang efektif dapat lebih menyelaraskan preferensi siswa mengenai karir yang akan ditempuh dengan kebutuhan pasar tenaga kerja (OECD, 2010, p.58). Pilihan karir yang akan ditempuh oleh siswa tidak selalu sejalan dengan kebutuhan akan pasar tenaga kerja. Banyak sekali faktor yang mempengaruhi pilihan karir siswa. Heckhausen \& Tomasik (2002, pp.199-219) menyatakan, biasanya pilihan karir didasarkan pada apa yang disukai dan apa yang individu prasangkakan terhadap suatu pekerjaan. Prasangka siswa terhadap suatu pekerjaan biasanya sama dengan nilai gengsi pekerjaan di masyarakat, namun pekerjaan yang menjadi impian siswa tersebut dapat berubah. Oleh karena itu melalui pemberian bimbingan karir diharapkan dapat membuka wawasan siswa mengenai prospek dari pekerjaan atau karir yang dapat ditempuh, sehingga siswa dapat memilih pekerjaan dengan tepat dan dapat memenuhi kebutuhan pasar tenaga kerja.

Istianyani (2012, pp.143-147) menyatakan terdapat beberapa layanan BKK yang dapat meningkatkan keterserapan lulusan ke dunia kerja diantaranya adalah sebagai berikut, (1) layanan informasi kerja, (2) jobfair, (3) recruitment, (4) assesment, (5) training, career dan professional development, serta (6) hubungan alumni. Di negara lain, lembaga penyaluran lulusan atau calon tenaga kerja disebut dengan placement office. Tidak jauh berbeda mengenai layanan yang diberikan oleh BKK seperti yang telah dijelaskan di atas, Ferguson (2007, p.37) menyatakan bahwa placement office ini akan memberikan beberapa pelayanan untuk membantu seseorang mendapatkan pekerjaan yaitu diantaranya adalah, (1) membantu mengidentifikasi keterampilan dan kemampuan serta mengidentifikasi pekerjaan yang sesuai; (2) membantu dalam membangun skill untuk mendapatkan pekerjaan seperti kemampuan dalam menyelesaikan surat menyurat dan melengkapi persyaratan untuk melamar pekerjaan, mempersiapkan diri dalam menghadapi wawancara kerja, dan mengembangkan kemampuan 
dalam memasarkan diri; (3) membantu mengirimkan berkas lamaran pekerjaan ke perusahaan atau tempat kerja yang kita inginkan.

Untuk mencapai tujuan yang telah ditetapkan, perlu adanya langkah-langkah atau upaya yang sistematis yang harus dipenuhi. Dinas Pendidikan Jateng (2010, p.15) telah merumuskan beberapa hal yang perlu diperhatikan agar kegiatan pengelolaan BKK dapat tercapai sesuai dengan rencana program, kondusif dan inovatif: (1) Pengelolaan BKK secara profesional; (2) Pengelolaan calon alumni secara optimal; (3) Pendekatan DU/DI secara intensif; (4) Membangun kemitraan jejaring dengan stakeholder.

Engelland, Workman, \& Singh (2000, pp. 236-245) menyatakan bahwa layanan karir dan penempatan kerja yang berkualitas tinggi, apabila dapat menyediakan berbagai macam konseling karir dan informasi penempatan kerja. Tujuannya adalah ketika siswa atau lulusan memasuki dunia kerja, mereka siap untuk membuat keputusan pilihan pekerjaan yang lebih baik yang mengarah ke karir yang lebih memuaskan dan produktif.

Indikator keberhasilan layanan karir dan penempatan kerja atau di SMK disebut dengan BKK, diutarakan oleh Dinas Pendidikan Jawa Tengah (2010, pp.22), dimana hal tersebut dapat diukur dengan kriteria sebagai berikut, (1) Tercapainya pelayanan informasi ketenagakerjaan pada tamatan SMK; (2) Adanya data tamatan SMK yang valid sesuai dengan kuailifikasi alumni; (3) Adanya data keterserapan tamatan SMK; (4) Adanya data penelusuran tamatan; (5) Tercapainya pengembangan hubungan kerjasama dengan DU/DI yang dibuktikan dengan adanya MoU; (6) Terjalinnya hubungan alumni SMK dengan sekolah yang dibuktikan dengan terbentuknya ikatan alumni dari SMK tersebut; (7) Adanya sinkronisasi pembelajaran antara DU/DI dengan sekolah; (8) Adanya pembelajaran soft skill, sebagai bekal masuk dunia kerja.

Kinerja BKK

BKK merupakan salah satu organisasi yang terdapat di SMK. Terdapat beberapa ahli yang telah mendefinisikan pengertian kinerja suatu organisasi. Walter (2005, p.937) me- nyatakan bahwa kinerja atau performance adalah seberapa baik seseorang, mesin, atau subjek lainnya melakukan suatu pekerjaan atau aktivitas. Apabila dikaitkan dengan organisasi maka dapat dinyatakan bahwa kinerja suatu organisasi adalah seberapa baik suatu organisasi melakukan pekerjaan atau apa yang menjadi tugasnya.

Rivai, et.al. (2011, p.16) mendefinisikan kinerja sebagai berikut, "Kinerja adalah hasil kerja yang dapat dicapai oleh seseorang atau sekelompok orang dalam suatu organisasi, sesuai dengan wewenang dan tanggung jawab masing-masing dalam rangka mencapai tujuan organisasi bersangkutan secara legal, tidak melanggar hukum, dan sesuai dengan moral maupun etika". Talbot (2010, p.1) menjelaskan pengertian kinerja suatu organisasi dengan istilah "seberapa baik organisasi tersebut melakukan usaha untuk mencapai tujuannya".

Berdasarkan pendapat-pendapat para ahli di atas, banyak yang menyoroti kinerja organisasi dilihat dari usaha yang dilakukan untuk mewujudkan tujuan, dan hasil pencapian atau produk yang dihasilkan oleh suatu organisasi. Apabila pendapat-pendapat di atas dikaitkan dengan kinerja BKK, maka dapat didefinisikan bahwa kinerja BKK adalah seberapa baik pelaksanaan tugas dan tingkat pencapaian tujuan atau hasil yang dicapai BKK.

Dimensi kinerja BKK dapat dibagi menjadi tiga yaitu dimensi input, proses dan output. Indikator kinerja dari masing-masing dimensi tersebut adalah sebagai berikut:

\section{Dimensi Input Kinerja BKK}

Input kinerja BKK adalah setiap sumber daya dari BKK yang menunjang untuk keberhasilan pencapaian tujuan. Melalui usaha pengukuran input atau sumber daya tersebut, maka dapat dianalisis kelengkapan sumber daya BKK dan kesesuaiannya dengan program atau kegiatan yang idealnya dilaksanakan oleh BKK. Apabila dikelompokkan indikator kinerja BKK dari sisi input terdiri dari: (1) BKK memiliki dana/anggaran yang cukup; (2) BKK memiliki sumber daya manusia yang memadai; (3) BKK memiliki perlengkapan penunjang yang lengkap; (4) BKK memiliki sarana dan prasarana yang lengkap dan memadai. 


\section{Dimensi Proses Kinerja BKK}

Proses merupakan serangkaian kegiatan yang dilakukan untuk mencapai tujuan. Indikator proses atau rangkaian kegiatan yang harus dilaksanakan oleh BKK yang telah disintesiskan dari buku petunjuk teknis, buku pedoman dan pendapat dari para ahli adalah sebagai berikut: (1) Layanan informasi ketenagakerjaan yang terdiri dari, (a) Terlaksananya program penginformasian lowongan pekerjaan kepada siswa atau lulusan melalui berbagai media; (b) BKK memanfaatkan teknologi informasi untuk menunjang pelayanannya; (c) BKK selalu meng-update informasi lowongan pekerjaan kepada siswa dan alumni; (d) Pengurus BKK memberikan pelayanan informasi ketenagakerjaan dengan baik. (2) Layanan bimbingan karir dan peningkatan skill dalam mencari dan melamar pekerjaan, terdiri dari: (a) BKK memberikan bimbingan pemilihan karir kepada siswa sesuai dengan bakat dan minatnya; (b) Adanya pembelajaran soft skill, sebagai bekal masuk dunia kerja dengan menghadirkan narasumber dari perusahaan atau biro konsultasi; (c) Adanya program seminar, pelatihan atau workshop mengenai manajemen karir dan strategi dalam mencari lowongan pekerjaan; (d) Adanya pelatihan kemampuan dalam menyelesaikan surat menyurat dan melengkapi persyaratan untuk melamar pekerjaan, mempersiapkan diri dalam menghadapi wawancara kerja, dan mengembangkan kemampuan dalam memasarkan diri. (3) Membangun kerja sama dengan DU/DI terdiri dari kegiatan sebagai berikut; (a) BKK melakukan promosi ke DU/DI melalui surat/ kunjungan langsung/internet untuk menjalin kerjasama; (b) BKK memelihara hubungan baik dengan DU/DI secara personal; (c) BKK memberikan kandidat calon tenaga kerja yang sesuai dengan kebutuhan DU/DI; (d) Adanya MoU kerjasama dalam bidang proses rekrutmen; (e) Adanya sinkronisasi pembelajaran di sekolah dengan kebutuhan tenaga kerja DU/ DI. (4) Membangun kemitraan jejaring dengan stakeholder terdiri dari kegiatan sebagai berikut: (a) BKK membangun komunikasi yang harmonis dengan kepala sekolah/guru karyawan, Dikpora, Disnaker, dan Pemerintah Daerah; (b) BKK melakukan kerja sama dengan BKK lain melalui asosiasi atau forum komunikasi. (5) Perencanaan tenaga kerja dan keleng- kapan data administrasi calon alumni terdiri dari kegiatan sebagai berikut: (a) BKK membuat perencanaan tenaga kerja berdasarkan minat, bakat dan kompetensi keahlian siswa; (b) BKK melakukan pendataan dan klasifikasi siswa berdasarkan fisik, usia, nilai, jurusan, dan jenis kelamin secara periodik; (c) BKK melakukan komputerisasi data base calon alumni. (6) Aspek layanan rekrutmen terdiri dari kegiatan sebagai berikut: (a) BKK membantu mengirimkan berkas lamaran pekerjaan ke perusahaan atau tempat kerja; (b) Terlaksananya job fair setiap tahunnya; (c) Terlaksananya rekrutmen secara rutin. (7) Membangun hubungan yang kuat dengan alumni, terdiri dari kegiatan sebagai berikut: (a) BKK melakukan pendataan dan penelusuran alumni; (b) Terbentuknya ikatan alumni; (c) BKK membangun komunikasi yang intensif dengan alumni.

\section{Dimensi Output Kinerja BKK}

Produk atau output dari BKK merupakan hasil yang dicapai dari pelaksanaan programprogram yang secara ideal dapat dilakukan oleh BKK. Indikator dari produk atau output dari BKK ini diantaranya adalah sebagai berikut: (1) Tersampaikannya informasi ketenagakerjaan kepada siswa; (2) Siswa memiliki pengetahuan mengenai dunia kerja, dapat memilih karir atau pekerjaan yang sesuai, dan memiliki keterampilan dalam mencari serta mendaftar pekerjaan; (3) Terjalinnya hubungan yang luas dan kuat dengan DU/DI; (4) Tersalurkannya lulusan ke dunia kerja; (5) Adanya perencanaan tenaga kerja setiap tahunnya; (6) Terjalinnya hubungan yang kuat dengan alumni.

\section{Model Evaluasi Kinerja}

Evaluasi merupakan langkah yang dapat digunakan untuk mengetahui kinerja BKK, pengertian evaluasi telah diinterpretasikan oleh beberapa ahli. Stufflebeam \& Shinkfield (1984, p.3) menyatakan pengertian evaluasi sebagai berikut, "evaluation is the systematic assessment of the worth or merit of some object". Di mana evaluasi merupakan penilaian yang sistematik dari kelayakan atau kebaikan dari suatu obyek.

Alkin $(2011$, p.9) mendefinisikan pengertian evaluasi yang hampir sama yaitu, "evaluation is judging the merit or worth of an entity", 
di mana intinya evaluasi merupakan penilaian kelayakan atau kebaikan dari suatu yang ada. Fitzpatrick, Sanders \& Worthen (2004, p.5) mendefinisikan pengertian evaluasi sebagai berikut, "evaluation as the identification, clarification, and application of defensible criteria to determine an evaluation object's value (worth or merit) in relation to those criteria". Pendapat tersebut mengandung makna bahwa evaluasi sebagai langkah identifikasi, klarifikasi dan penerapan dari kriteria yang dapat dipertahankan untuk menentukan nilai (kelayakan atau kebaikan) dari obyek evaluasi dalam hubungannya dengan kriteria tersebut.

Wholey, Hatry \& Newcomer (2010, p.5) menyatakan bahwa evaluasi program merupakan penerapan dari metode yang sistematis untuk menjawab pertanyaan tentang pelaksanaan dan hasil dari suatu program. Pendapat lainnya diungkapkan oleh Spaulding (2008, p.5), di mana kegiatan evaluasi tidak hanya kegiatan untuk menentukan kelayakan dan kebaikan dari suatu program, namun juga untuk membuat rekomendasi untuk perbaikan dan mencapai keberhasilan. Berdasarkan pendapat dari ahli di atas dapat disimpulkan bahwa evaluasi merupakan serangkaian proses yang sistematis untuk menentukan nilai dari obyek yang dievaluasi berdasarkan kriteria yang telah ditetapkan, untuk membuat rekomendasi untuk perbaikan dan pencapaian tujuan.

Terdapat beberapa pendekatan yang dapat digunakan untuk melaksanakan evaluasi terhadap suatu program, Fitzpatrick, Sanders \& Worthen (2004, p.68) mengklasifikasikannya menjadi lima kategori yaitu diantaranya adalah sebagai berikut: "(1) objectives-oriented approaches; (2) management-oriented approaches; (3) consumer-oriented approaches; (4) expertise-oriented approaches; (5)participantoriented approaches".

Pendekatan evaluasi yang paling cocok untuk melakukan evaluasi kinerja BKK berdasarkan kelima pendekatan di atas adalah objectives-oriented approaches. Hal ini sesuai dengan pengertian dari kinerja BKK yang telah dibangun yaitu seberapa baik pelaksanaan tugas dan tingkat pencapaian tujuan atau hasil yang dicapai BKK. Di mana pengukuran dan evaluasi kinerja BKK berfokus pada keterlak- sanaan tugas dan tingkat pencapaian tujuan atau hasil yang dicapai BKK.

Model evaluasi dari objectives-oriented approaches yang dipilih adalah model evaluasi discrepancy dari provus. Kaufman \& Thomas (1980, p.127) menyatakan model penelitian evaluasi ini berorientasi pada pengukuran kesenjangan di dalam pelaksanaan program. Pendapat lain mengenai model penelitian evaluasi ini yang senada dengan pendapat di atas, disampaikan oleh Madaus, Scriven \& Stufflebeam $(1986$, p.80) yaitu "...evaluation as being a matter of making judgements about the worth or adequacy of an object based upon $D$ (Discrepancy) information between S (Standard) and P (Performance)". Pendapat tersebut menjelaskan bahwa evaluasi sama dengan kegiatan pembuatan penilaian tentang kelayakan atau kecukupan suatu obyek berdasarkan informasi kesenjangan (D) antara standar (S) dan kinerja (P).

Melalui model evaluasi discrepancy, dapat diketahui kesenjangan yang terjadi pada dimensi kinerja BKK yang terdiri dari dimensi input, proses, dan output. Sehingga dapat diidentifikasi aspek-aspek yang masih mengalami kesenjangan yang besar dan membutuhkan perbaikan. Informasi dari hasil evaluasi tersebut dapat digunakan sebagai acuan untuk memetakan dan melakukan analisis prioritas perbaikan yang harus dilaksanakan.

Langkah pelaksanaan evaluasi model discrepancy terdapat beberapa tahapan diantaranya adalah sebagai berikut (Fitzpatrick, Sanders \& Worthen, 2004, p.75): (1) Membuat standar; (2) Menentukan kesenjangan yang terjadi antara kinerja pada kondisi nyata dari beberapa aspek dalam program dengan standar yang telah ditetapkan; (3) Menggunakan informasi dari kesenjangan tersebut untuk memberikan rekomendasi untuk meningkatkan, menjaga atau menghentikan program atau beberapa aspek dari program tersebut.

\section{METODE PENELITIAN}

\section{Jenis Penelitian}

Penelitian ini termasuk dalam penelitian evaluasi dengan model discrepancy dari provus. 
Tabel 2. Jumlah Sampel Siswa

\begin{tabular}{llcc}
\hline No & Nama Sekolah & Jumlah Siswa & Jumlah Sampel \\
\hline 1 & SMKN 2 Depok & 398 & 121 \\
2 & SMKN 1 Seyegan & 358 & 110 \\
3 & SMKN 1 Cangkringan & 51 & 16 \\
\hline Jumlah & $\mathbf{8 0 7}$ & $\mathbf{2 4 7}$ \\
\hline
\end{tabular}

Tabel 3. Kriteria Penilaian Kinerja

\begin{tabular}{llc}
\hline No & Interval Nilai & Kategori Kinerja \\
\hline 1 & Skor $>\mathrm{Mi}+1,5 \mathrm{SDi}$ & Sangat baik \\
2 & $\mathrm{Mi} \leq \mathrm{Skor}<\mathrm{Mi}+1,5 \mathrm{SDi}$ & Baik \\
3 & $\mathrm{Mi}-1,5 \mathrm{SDi} \leq \mathrm{Skor}<\mathrm{Mi}$ & Rendah \\
4 & Skor $<\mathrm{Mi}-1,5 \mathrm{SDi}$ & Sangat rendah \\
\hline
\end{tabular}

Keterangan:

$\mathrm{Mi}=1 / 2($ skor ideal maksimum + skor ideal minimum $)$

SDi $=1 / 6$ (skor ideal maksimum - skor ideal minimum)

\section{Waktu dan Tempat Penelitian}

Penelitian dilaksanakan di SMK Negeri Bidang Keahlian Teknologi dan Rekayasa di Kabupaten Sleman yang terdiri dari SMKN 2 Depok, SMKN 1 Seyegan, SMKN 1 Cangkringan. Adapun penelitian ini dilaksanakan pada bulan Februari-April 2014.

\section{Responden Penelitian}

Responden pada penelitian ini adalah pengurus BKK dan siswa tingkat akhir di SMK yaitu kelas XII untuk SMK dengan pendidikan tiga tahun dan kelas XIII untuk SMK dengan pendidikan 4 tahun. Jumlah pengurus BKK di setiap SMK idealnya (sesuai petunjuk teknis BKK) adalah 6 orang. Namun responden dari pengurus BKK ini disesuaikan dengan jumlah nyata pengurus yang ada di sekolah.

Pengambilan sampel penelitian dilakukan terhadap responden siswa dengan teknik proportional random sampling. Jumlah sampel ditentukan dengan tabel dari Isaac dan Michael dengan tingkat kesalahan 5\%. Pembagian jumlah sampel setiap sekolah dapat dilihat pada tabel 2 .

\section{Variabel Penelitian}

Penelitian ini memiliki variabel mandiri yaitu kinerja bursa kerja khusus (BKK) SMK. Kinerja BKK dapat dinyatakan dengan seber- apa baik pelaksanaan tugas, dan tingkat pencapaian tujuan atau hasil yang dicapai BKK. Kinerja BKK dilihat dari 3 dimensi yaitu input, proses, dan output.

\section{Teknik dan Instrumen Pengumpulan Data}

Instrumen yang digunakan pada penelitian ini berupa inventori, lembar observasi, lembar dokumentasi, dan pedoman wawancara. Setiap butir pada instrumen inventori, lembar observasi, lembar dokumentasi memiliki empat alternatif jawaban, skor dari pilihan yang mengindikasikan kondisi paling baik adalah 4 dan skor terendahnya adalah 1 . Wawancara terbatas dilakukan untuk menggali informasi dari temuan penelitian di lapangan yang menarik.

\section{Validitas Instrumen}

Pengujian validitas instrumen dilakukan dengan validitas isi yaitu dengan penilaian dari ahli atau expert judgement.

\section{Teknik Analisis Data}

Teknik analisis data yang digunakan pada penelitian ini adalah menggunakan statistik diskriptif yaitu mean, median, modus dan perhitungan persentase untuk menghitung discrepancy yang terjadi. Berdasarkan adaptasi pendapat dari Mardapi (2008, pp.122-123), kemudian data dikelompokkan berdasarkan pengkategorian seperti tertera pada tabel 3 . 
Tabel 4. Kriteria Discrepancy dan Rekomendasi

\begin{tabular}{llll}
\hline No & Nilai & Kategori & \\
& Discrepancy & Discrepancy & Rekomendasi \\
\hline 1 & $D<25 \%$ & Sangat Kecil & Kinerja Dipertahankan/Butuh Sangat Sedikit Pembenahan \\
2 & $25 \% \leq D<50 \%$ & Kecil & Butuh Sedikit Pembenahan \\
3 & $50 \% \leq D<75 \%$ & Tinggi & Butuh Banyak Pembenahan \\
4 & $D>75 \%$ & Sangat Tinggi & Butuh Sangat Banyak Pembenahan \\
\hline
\end{tabular}

Keterangan: $\mathrm{D}=$ Discrepancy

Tabel 5. Kinerja BKK Ditinjau dari Dimensi Input

\begin{tabular}{llll}
\hline BKK & SMKN 2 Depok & SMKN 1 Seyegan & SMKN 1 Cangkringan \\
\hline Skor Total & 69 & 48,7 & 38 \\
Kinerja & Baik & Rendah & Sangat Rendah \\
Discrepancy (\%) & 33,33 & 62,75 & 78,26 \\
Kategori Discrepancy & Rendah & Tinggi & Sangat Tinggi \\
\hline
\end{tabular}

Untuk pengolahan data statistik dan memperjelas penyajian data hasil penelitian, maka analisis data dilakukan dengan bantuan program microsoft excel. Kinerja BKK SMK Negeri Bidang Keahlian Teknologi dan Rekayasa di Kabupaten Sleman secara umum pada tiap dimensi diperoleh dengan merata-rata skor kinerja BKK dari ketiga SMK yang dijadikan tempat penelitian.

Besarnya persentase discrepancy dihitung dengan rumus sebagai berikut:

Discrepacy $(\%)=100 \%=\left\{\left(\frac{\text { Skor yang diperoleh }- \text { skor ideal min imum }}{\text { Skor idel maksimum }- \text { skor ideal min imum }}\right) \times 100 \%\right\}$

Kriteria rekomendasi untuk discrepancy atau kesenjangan yang terjadi tiap dimensi atau indikatornya adalah sebagai berikut:

\section{HASIL PENELITIAN DAN PEMBAHASAN}

Kinerja BKK SMK Negeri Bidang Keahlian Teknologi dan Rekayasa di Kabupaten Sleman ditinjau dari dimensi input

Berdasarkan hasil penelitian, skor kinerja BKK SMK Negeri Bidang Keahlian Teknologi dan Rekayasa di Kabupaten Sleman ditinjau dari dimensi input dapat dilihat pada tabel 5.

Penentuan tingkat kinerja dari BKK masing-masing SMK pada dimensi input, diperoleh dengan membandingkan skor total pada dimensi input dengan kriteria penilaian kinerja dimensi input pada tabel 6 di bawah.

Tabel 6. Kriteria Penilaian Kinerja Dimensi Input

\begin{tabular}{cll}
\hline No & Interval Nilai/Skor & Kategori \\
\hline 1 & SKOR $>74,75$ & Sangat Baik \\
2 & $57,5 \leq$ SKOR $<74,75$ & Baik \\
3 & $40,25 \leq$ SKOR $<57,5$ & Rendah \\
4 & SKOR $<40,25$ & Sangat Rendah \\
\hline
\end{tabular}

Kinerja BKK SMK Negeri Bidang Keahlian Teknologi dan Rekayasa di Kabupaten Sleman secara umum pada dimensi ini dapat dilihat pada tabel 7 di bawah. Penentuan kinerjanya diperoleh dengan merata-rata skor kinerja BKK dari masing-masing SMK. Kemudian membandingkannya dengan tabel kriteria penilaian kinerja dimensi input seperti yang tertera pada tabel 6 di atas.

Tabel 7. Kinerja BKK SMK secara Umum Ditinjau dari Dimensi Input

\begin{tabular}{clc}
\hline No & BKK & $\begin{array}{c}\text { Skor Dimensi } \\
\text { Input }\end{array}$ \\
\hline $1 \quad$ SMKN 2 Depok & 69 \\
2 & SMKN 1 Seyegan & 48,7 \\
3 & SMKN 1 Cangkringan & 38 \\
\hline Rata-Rata & 51,9 \\
Kategori Kinerja & Rendah \\
Discrepancy (\%) & 58.12 \\
Kategori Discrepancy & Tinggi \\
\hline
\end{tabular}




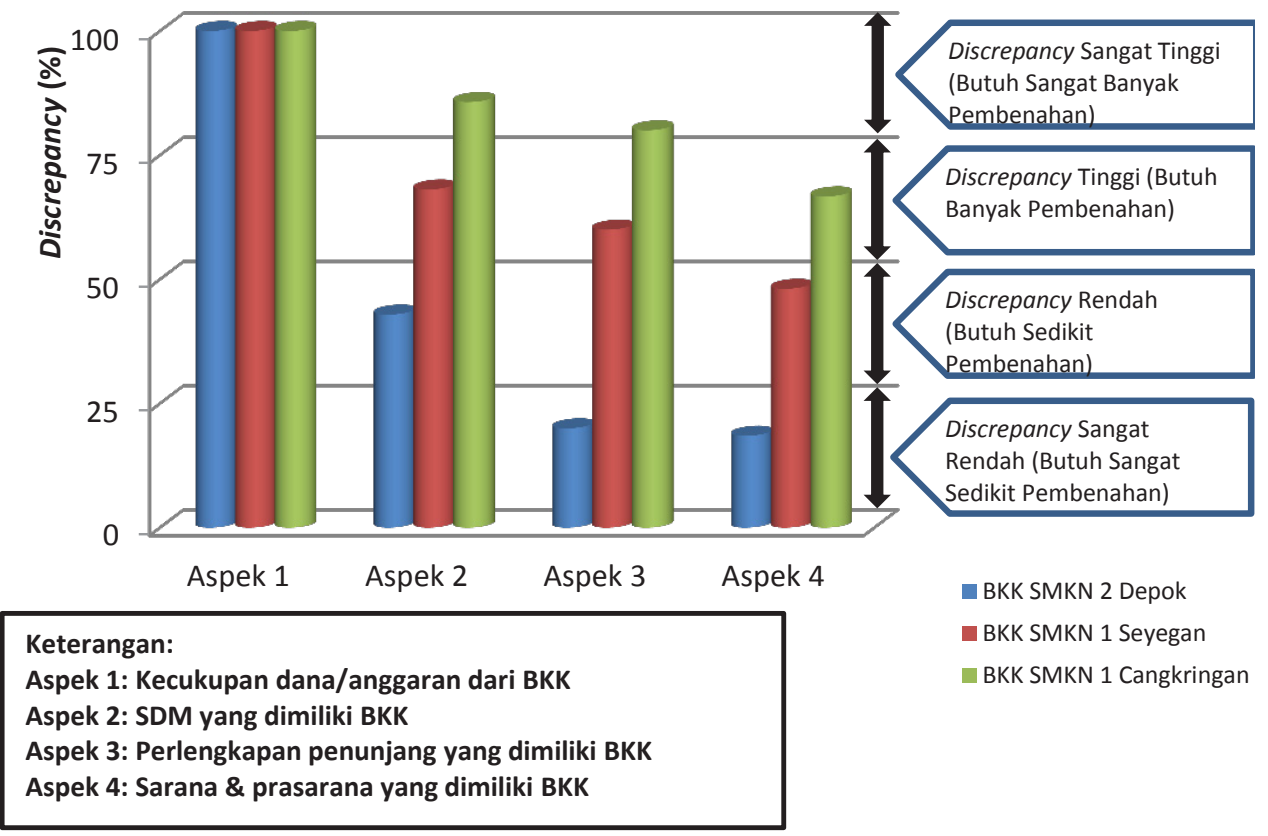

Gambar 1. Diagram Discrepancy dan Rekomendasi pada Dimensi Input

Suatu organisasi harus memiliki sumber daya atau input yang memadai untuk dapat bekerja dengan optimal. Namun BKK SMK Negeri Bidang Keahlian Teknologi dan Rekayasa di Kabupaten Sleman secara umum masih memiliki input yang rendah. Belum semua BKK memiliki input atau sumber daya yang baik atau mencukupi. Berdasarkan hasil penelitian dari tiga sekolah hanya SMKN 2 Depok yang memiliki sumber daya atau input yang masuk dalam kategori baik, sedangkan SMKN 1 Seyegan memiliki kinerja pada aspek input yang rendah dan SMKN 1 Cangkringan masuk dalam kategori sangat rendah. Hal ini tentunya akan berpengaruh terhadap kinerja BKK dalam mewujudkan tujuan dan program yang telah direncanakan. Masih rendahnya input dari BKK ini juga membuktikan perhatian dari sekolah maupun dari pemerintah mengenai penyelenggaraan BKK yang masih rendah. Rincian kesenjangan atau discrepancy yang terjadi di setiap aspek pada dimensi input dari ketiga BKK dapat dilihat pada gambar 1.

Kesenjangan atau discrepancy yang masih besar dari aspek input, yang dialami oleh ketiga BKK adalah pada aspek pendanaan. Berdasarkan hasil penelitian diperoleh hasil bahwa dari setiap sekolah tidak terdapat pen- danaan khusus dari sekolah untuk penyelenggaraan program-program BKK. Padahal untuk operasional kegiatan BKK membutuhkan dana yang cukup besar.

Ditinjau dari aspek jumlah personil dari ketiga BKK masih mengalami kekurangan personil dan belum sesuai dengan petunjuk teknis pelaksanaan BKK dan beban kerjanya masih terlalu tinggi. Pengembangan kompetensi pengurus BKK juga perlu diperhatikan, agar pengelolaan BKK dapat sesuai dengan yang diharapkan. Selain itu, dari aspek perlengkapan penunjang dan sarana prasarana juga masih terdapat BKK yang masih belum lengkap.

Setiap discrepancy atau kesenjangan yang terjadi pada dimensi input perlu dilakukan pembenahan. Pembenahan dalam hal ini adalah melakukan penambahan dan perbaikan dari aspek input yang masih mengalami kekurangan. Prioritas pembenahan dapat dilakukan berdasarkan discrepancy yang terjadi pada tiap aspek. Pembenahan pada dimensi input merupakan pondasi untuk melakukan pembenahan pada dimensi lainnya karena dimensi input yang kurang memadai akan berpengaruh pada aspek proses dan output dari BKK yang menjadi tidak maksimal. 
Tabel 8. Kinerja BKK Ditinjau dari Dimensi Proses

\begin{tabular}{lccc}
\hline BKK & SMKN 2 Depok & SMKN 1 Seyegan & SMKN 1 Cangkringan \\
\hline Skor Total & 183,78 & 132,2 & 110,1 \\
Kinerja & Baik & Rendah & Rendah \\
Discrepancy (\%) & 27,71 & 57,37 & 70,05 \\
Kategori Discrepancy & Rendah & Tinggi & Tinggi \\
\hline
\end{tabular}

Kinerja BKK SMK Negeri Bidang Keahlian Teknologi dan Rekayasa di Kabupaten Sleman ditinjau dari dimensi proses

Penilaian pada dimensi proses merupakan penilaian terhadap pelaksanaan tugas-tugas BKK. Berdasarkan hasil penelitian, skor kinerja BKK SMK Negeri Bidang Keahlian Teknologi dan Rekayasa di Kabupaten Sleman ditinjau dari dimensi proses dapat dilihat pada tabel 8 .

Penentuan tingkat kinerja dari masingmasing BKK SMK pada dimensi proses, diperoleh dengan membandingkan skor total pada aspek proses dengan kriteria penilaian kinerja pada tabel 9.

Tabel 9. Kriteria Penilaian Kinerja Dimensi Proses

\begin{tabular}{cll}
\hline No & Interval Nilai/Skor & Kategori \\
\hline 1 & SKOR $>188,5$ & Sangat Baik \\
2 & $145 \leq$ SKOR $<188,5$ & Baik \\
3 & $101,5 \leq$ SKOR $<145$ & Rendah \\
4 & SKOR $<101,5$ & Sangat Rendah \\
\hline
\end{tabular}

Kinerja BKK SMK Negeri Bidang Keahlian Teknologi dan Rekayasa di Kabupaten Sleman secara umum diperoleh dengan merata-rata skor kinerja BKK dari masing-masing SMK. Kemudian membandingkannya dengan tabel kriteria penilaian kinerja dimensi proses seperti yang tertera pada tabel 9 di atas.

Tabel 10. Kinerja BKK SMK secara Umum Ditinjau dari Dimensi Proses

\begin{tabular}{clc}
\hline No & BKK & $\begin{array}{c}\text { Skor Dimensi } \\
\text { Proses }\end{array}$ \\
\hline 1 & SMKN 2 Depok & 183,78 \\
2 & SMKN 1 Seyegan & 132,17 \\
3 & SMKN 1 Cangkringan & 110,12 \\
\hline Rata-Rata & 142 \\
Kategori Kinerja & Rendah \\
Discrepancy (\%) & 51,71 \\
Kategori Discrepancy & Tinggi \\
\hline
\end{tabular}

Berdasarkan hasil penelitian, kinerja BKK SMK Negeri Bidang Keahlian Teknologi dan Rekayasa di Kabupaten Sleman ditinjau dari dimensi proses secara umum masih masuk dalam kategori rendah. Apabila dilihat kinerja BKK pada dimensi proses ditiap SMK, BKK SMKN 2 Depok memiliki kinerja yang baik, sedangkan BKK SMKN 1 Seyegan dan BKK SMKN 1 Cangkringan memiliki kinerja yang masih rendah. Berdasarkan hasil tersebut menunjukkan bahwa masih terdapat BKK yang belum melaksanakan tugasnya dengan optimal.

Hasil penelitian menunjukkan bahwa pada dimensi ini, BKK SMKN 2 Depok memiliki satu aspek yang membutuhkan banyak pembenahan. BKK SMKN 1 Seyegan terdapat empat aspek yang memiliki discrepancy yang besar atau sangat besar, sedangkan untuk BKK SMKN 1 Cangkringan masih memiliki 6 aspek yang memiliki discrepancy besar atau sangat besar. Rincian discrepancy yang terjadi pada setiap aspek untuk dimensi proses dari ketiga BKK tersebut dapat dilihat pada gambar 2 di bawah.

Aspek layanan informasi ketenagakerjaan dari ketiga sekolah masih memiliki discrepancy yang besar, di mana media yang digunakan masih belum memaksimalkan media komunikasi yang tersedia dan masih berpusat pada papan pengumuman lowongan pekerjaan di sekolah. Pelaksanaan job hunting dari pengurus BKK untuk menjaring informasi lowongan pekerjaan juga masih rendah hal ini tentunya akan berakibat masih minimnya informasi lowongan pekerjaan yang relevan yang diterima siswa.

Dalam hal pelaksanaan layanan bimbingan karir hanya BKK SMKN 1 Cangkringan yang memiliki discrepancy yang sangat besar. Aspek ini merupakan komponen yang penting untuk membangun skill dan wawasan siswa 


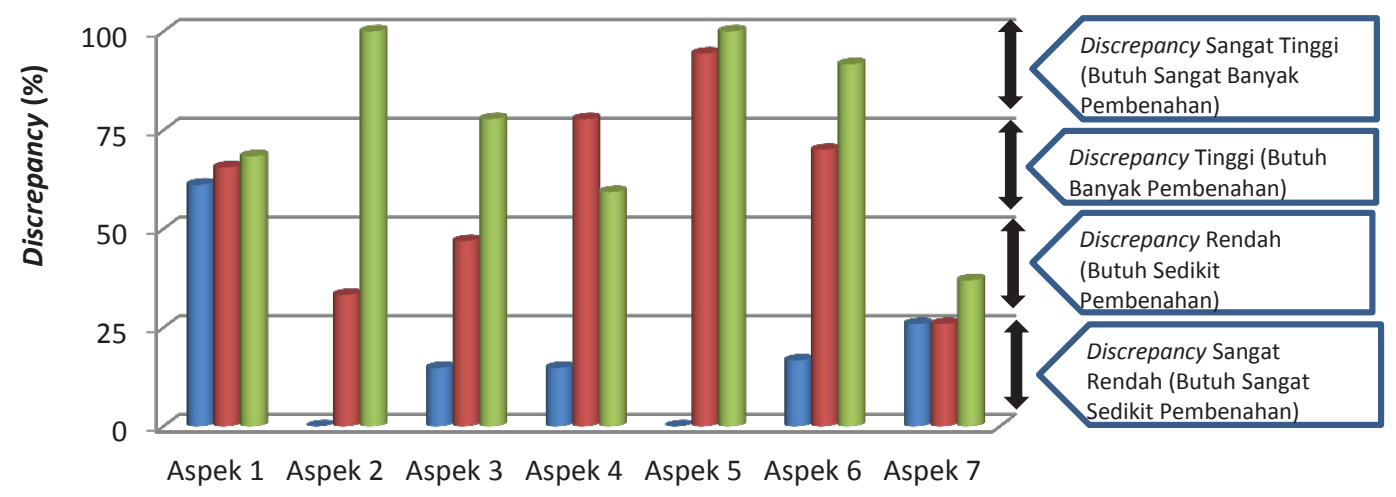

Keterangan:

Aspek 1 : Pelaksanaan layanan informasi ketenagakerjaan

BKK SMKN 2 Depok

Aspek 2 : Pelaksanaan layanan bimbingan karir dan peningkatan skill dalam mencari pekerjaan

Aspek 3 : Pelaksanaan usaha membangun kerjasama dengan DU/DI

- BKK SMKN 1 Seyegan

BKK SMKN 1 Cangkringan

Aspek 4 : Pelaksanaan usaha membangun kemitraan jejaring dengan stakeholder

Aspek 5 : Pelaksanaan perencanaan tenaga kerja dan kelengkapan data administrasi calon alumni

Aspek 6 : Pelaksanaan layanan rekrutmen

Aspek 7 : Pelaksanaan usaha membangun hubungan yang kuat dengan alumni

Gambar 2. Diagram Discrepancy dan Rekomendasi pada Dimensi Proses

dalam bidang karir sehingga harus dilaksanakan secara periodik dan terencana dengan baik.

Pelaksanaan usaha dalam membangun kerja sama dengan DU/DI dan stakeholder dari SMKN 1 Seyegan dan SMKN 1 Cangkringan perlu dilaksanakan dengan lebih baik karena mustahil untuk SMK dapat produktif menyalurkan dan memasarkan lulusannya dengan luas apabila tidak didasari dengan pondasi kerja sama dengan pihak-pihak terkait yang kuat.

Aspek perencanaan tenaga kerja dan kelengkapan data administrasi calon alumni pada SMKN 1 Seyegan dan SMKN 1 Cangkringan juga masih memiliki discrepancy yang sangat besar, atau dengan kata lain masih banyak kegiatan yang tidak dilaksanakan. BKK perlu membuat data perencanaan tenaga kerja dan data administrasi calon alumni, dengan data tersebut maka BKK dapat memetakan strategi, baik dalam memberikan bimbingan karir, target jumlah lowongan pekerjaan yang masuk ke BKK, dan memudahkan dalam melakukan penginformasian lowongan pekerjaan terutama yang sifatnya mendadak.
Aspek layanan rekrutmen pada SMKN 2 Depok sudah baik ini ditandai dengan adanya discrepancy yang sangat kecil, sedangkan untuk SMKN 1 Seyegan dan SMKN 1 Cangkringan masih memiliki discrepancy yang besar dan sangat besar. Untuk itu pada kedua SMK tersebut membutuhkan pembenahan supaya dapat menyelenggarakan rekrutmen maupun job fair dengan intensitas yang lebih banyak dan rutin. Melalui kegiatan tersebut maka diharapkan jumlah lulusan yang terserap ke dunia kerja menjadi lebih banyak jumlahnya.

Alumni dapat memberikan sumbangan dalam mendukung usaha dalam meningkatkan angka keterserapan lulusan ke dunia kerja apabila dijalin hubungan yang baik dan kuat. Ketiga BKK SMK sudah melaksanakan usaha tersebut. Namun pada aspek ini masih terdapat discrepancy walaupun masuk dalam kategori yang kecil, sehingga untuk memaksimalkannya pelaksanaannya perlu ditingkatkan lagi.

Berdasarkan pembahasan di atas, BKK SMKN 1 Seyegan dan SMKN 1 Cangkringan perlu melakukan banyak pembenahan pada dimensi ini, dan untuk BKK SMKN 2 Depok 
Tabel 11. Kinerja BKK Ditinjau dari Dimensi Output

\begin{tabular}{lccc}
\hline BKK & SMKN 2 Depok & SMKN 1 Seyegan & SMKN 1 Cangkringan \\
\hline Skor Total & 47,46 & 32,09 & 28,82 \\
Kinerja & Baik & Rendah & Sangat Rendah \\
Discrepancy (\%) & 45,44 & 73,91 & 79,96 \\
Kategori Discrepancy & Rendah & Tinggi & Sangat Tinggi \\
\hline
\end{tabular}

walaupun sudah masuk dalam kategori baik. Masih perlu melakukan sedikit pembenahan pada aspek yang masih mengalami kekurangan untuk mewujudkan pelaksanaan BKK yang lebih baik. Hal ini penting karena dimensi proses dari pelaksanaan kegiatan operasional BKK akan berhubungan dengan ketercapaian dari tujuan pelaksanaan kegiatan yang telah direncanakan.

Kinerja BKK SMK Negeri Bidang Keahlian Teknologi dan Rekayasa di Kabupaten Sleman ditinjau dari dimensi output

Berdasarkan hasil penelitian, skor kinerja BKK SMK Negeri Bidang Keahlian Teknologi dan Rekayasa di Kabupaten Sleman ditinjau dari dimensi output dapat dilihat pada tabel 11.

Penentuan tingkat kinerja dari masingmasing SMK pada dimensi output, diperoleh dengan membandingkan skor total pada aspek output dengan kriteria penilaian kinerja pada tabel 12 di bawah.

Tabel 12. Kriteria Penilaian Kinerja Dimensi Output

\begin{tabular}{cll}
\hline No & Interval Nilai/Skor & Kategori \\
\hline 1 & SKOR $>58,5$ & Sangat Baik \\
2 & $45 \leq$ SKOR $<58,5$ & Baik \\
3 & $31,5 \leq$ SKOR $<45$ & Rendah \\
4 & SKOR $<31,5$ & Sangat Rendah \\
\hline
\end{tabular}

Kinerja BKK SMK Negeri Bidang Keahlian Teknologi dan Rekayasa di Kabupaten Sleman secara umum pada dimensi output dapat dilihat pada tabel 13 di bawah. Penentuan kinerjanya diperoleh dengan merata-rata skor kinerja BKK dari masing-masing SMK. Kemudian membandingkannya dengan tabel kriteria penilaian kinerja dimensi output seperti yang tertera pada tabel $12 \mathrm{di}$ atas.
Tabel 13. Kinerja BKK SMK secara Umum Ditinjau dari Dimensi Output

\begin{tabular}{clc}
\hline No & BKK & $\begin{array}{c}\text { Skor Dimensi } \\
\text { Proses }\end{array}$ \\
\hline $1 \quad$ SMKN 2 Depok & 47,46 \\
2 & SMKN 1 Seyegan & 32,09 \\
3 & SMKN 1 Cangkringan & 28,82 \\
\hline Rata-Rata & 36,1 \\
Kategori Kinerja & Rendah \\
Discrepancy (\%) & 66,44 \\
Kategori Discrepancy & Tinggi \\
\hline
\end{tabular}

Berdasarkan hasil penelitian, kinerja BKK SMK Negeri Bidang Keahlian Teknologi dan Rekayasa di Kabupaten Sleman ditinjau dari dimensi output secara umum masih masuk dalam kategori rendah. Apabila dilihat kinerja BKK pada dimensi output ditiap SMK, BKK SMKN 2 Depok ditinjau dari dimensi output memiliki kinerja yang baik, sedangkan BKK SMKN 1 Seyegan dan BKK SMKN 1 Cangkringan memiliki kinerja yang masih rendah.

Hasil penelitian menunjukkan bahwa pada dimensi ini BKK SMKN 2 Depok masih memiliki aspek yang kesenjangannya masih besar seperti pada aspek tersampaikannya informasi ketenagakerjaan kepada siswa dan terjalinnya hubungan yang luas dan kuat dengan DU/DI. BKK SMK lainnya masih memiliki kinerja pada dimensi output yang rendah dan semua aspeknya masih memiliki kesenjangan yang besar dan sangat besar. Oleh karena itu pada kedua SMK tersebut membutuhkan pembenahan yang lebih banyak dan menyeluruh.

Dimensi output pada dasarnya sangat erat kaitannya dengan dimensi input dan proses yang telah dilaksanakan. Oleh karena itu, dimensi input dan proses perlu dipenuhi dan diperbaiki terlebih dahulu untuk meningkatkan output. Selain itu untuk meningkatkan output 


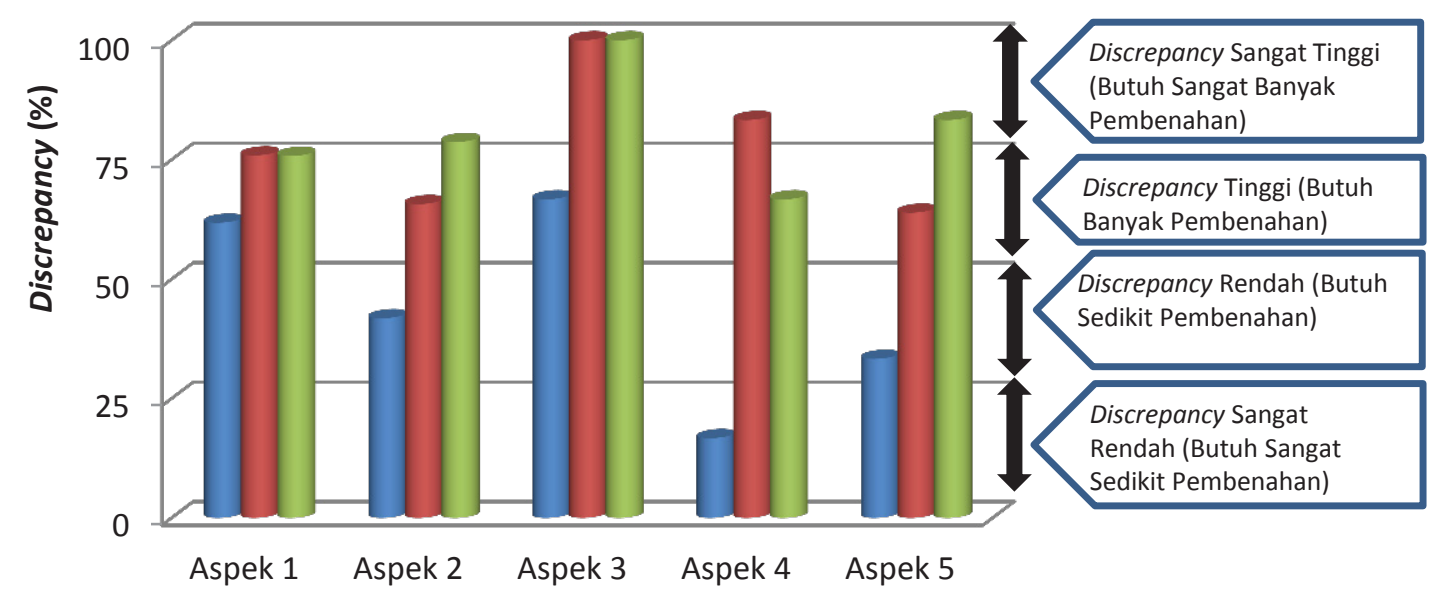

Keterangan:

Aspek 1 : Tingkat informasi ketenagakerjaan yang diterima siswa

Aspek 2 : Tingkat ketersampaian pengetahuan dalam bidang karir kepada siswa

Aspek 3 : Tingkat hubungan BKK dengan DU/DI

- BKK SMKN 2 Depok

BKK SMKN 1 Seyegan

BKK SMKN 1 Cangkringan

Aspek 4 : Tingkat penyaluran dan keterserapan lulusan ke dunia kerja

Aspek 5 : Tingkat hubungan BKK dengan alumni

Gambar 3. Diagram Discrepancy dan Rekomendasi pada Dimensi Output

juga dapat dilakukan dengan menambah kuantitas dan kualitas kegiatan yang dilaksanakan BKK.

Uraian mengenai discrepancy pada setiap indikator dari dimensi output dari masing-masing BKK di ketiga sekolah dapat dilihat pada gambar 3 .

\section{SIMPULAN DAN SARAN}

\section{Simpulan}

Berdasarkan hasil penelitian dan pembahasan mengenai kinerja BKK SMK Negeri Bidang Keahlian Teknologi dan Rekayasa, yang terdiri dari SMKN 2 Depok, SMKN 1 Seyegan dan SMKN 1 Cangkringan dapat disimpulkan bahwa: (1) Kinerja BKK SMK Negeri Bidang Keahlian Teknologi dan Rekayasa ditinjau dari dimensi input secara umum masuk dalam kategori rendah, dengan kesenjangan (discrepancy) sebesar 58.12\% (discrepancy tinggi). Rincian kinerja BKK ditinjau dari dimensi input dari masing-masing SMK adalah sebagai berikut: (a) BKK SMKN 2 Depok masuk dalam kategori baik dengan discrepancy sebesar 33.33\% (discrepancy rendah); (b) BKK SMKN 1 Seyegan masuk dalam kategori rendah dengan discrepancy sebesar $62.75 \%$ (discrepancy tinggi); (c) SMKN 1 Cangkringan masuk dalam kategori sangat rendah dengan discrepancy sebesar 78.26\% (discrepancy sangat tinggi). (2) Kinerja BKK SMK Negeri Bidang Keahlian Teknologi dan Rekayasa ditinjau dari dimensi proses secara umum masuk dalam kategori rendah dengan discrepancy sebesar 51.71\% (discrepancy tinggi). Rincian kinerja BKK ditinjau dari dimensi proses dari masing-masing SMK adalah sebagai berikut: (a) BKK SMKN 2 Depok masuk dalam kategori baik dengan discrepancy sebesar 27.71\% (discrepancy rendah); (b) BKK SMKN 1 Seyegan masuk dalam kategori rendah dengan discrepancy sebesar $57.37 \%$ (discrepancy tinggi); (c) SMKN 1 Cangkringan masuk dalam kategori rendah dengan discrepancy sebesar 70.05\% (discrepancy tinggi). (3) Kinerja BKK SMK Negeri Bidang Keahlian Teknologi dan Rekayasa ditinjau dari aspek output secara umum masuk dalam kategori rendah dengan discrepancy sebesar 51.71\% (discrepancy tinggi). Rincian kinerja BKK ditinjau dari dimensi output dari masing-masing SMK adalah sebagai berikut: (1) BKK SMKN 2 Depok masuk dalam kategori baik dengan discrepancy sebesar $45.44 \%$ (discrepancy rendah); (2) BKK SMKN 1 Seyegan masuk dalam kategori rendah dengan discrepancy sebesar $73.91 \%$ (discrepancy tinggi); 
(3) SMKN 1 Cangkringan masuk dalam kategori sangat rendah dengan discrepancy sebesar 79.96\% (discrepancy sangat tinggi).

Saran

Berdasarkan hasil penelitian, diajukan saran sebagai berikut: (1) Pemerintah perlu melakukan analisis kebutuhan dan pertimbangan dari segala aspek yang matang dalam usaha mengembangkan jumlah SMK menjadi 70:30 dibandingkan dengan jumlah SMA. Dengan demikian SMK yang dibangun atau dikembangkan tidak hanya meningkat secara kuantitas saja namun juga secara kualitas, serta relevan terhadap kebutuhan tenaga kerja yang ada. Melalui hal tersebut maka SMK sebagai solusi untuk menekan angka pengangguran dapat tercapai; (2) Disnaker perlu meningkatkan pembinaan, pengawasan dan kerja sama dengan BKK SMK sehingga BKK setiap SMK dapat terselenggara dengan baik dan selalu berkembang; (3) Dinas Pendidikan perlu memberikan perhatian dan dorongan dalam bentuk kebijakan yang dapat menunjang terlaksana dan berkembangnya BKK di SMK baik untuk sekolah swasta maupun negeri; (4) Sekolah perlu memenuhi sumber daya baik dari segi pendanaan, sarana dan prasarana, perlengkapan penunjang dan sumber daya manusia yang dibutuhkan untuk penyelenggaraan BKK dan mengelolanya dengan lebih baik sehingga kegiatan/program BKK dapat terselenggara dengan baik dan dapat meningkatkan angka keterserapan lulusan ke dunia kerja; (5) Bagi BKK, (a) BKK perlu mengoptimalkan kegiatan job hunting sehingga lowongan pekerjaan yang ada dapat terserap dan tersampaikan kepada siswa maupun lulusan dengan maksimal baik dari segi kuantitas dan relevansinya; (b) BKK perlu memperluas dan memperkuat jaringan kerja sama dengan DU/DI dan stakeholder lainnya sehingga kegiatan penyaluran dan penempatan lulusan dapat berjalan lebih luas dan optimal; (c) BKK perlu mengoptimalkan kegiatan bimbingan karir kepada siswa baik secara individu maupun secara klasikal untuk meningkatkan kemampuan siswa dalam memilih dan mengembangkan karirnya, serta dapat menyelaraskan preferensi siswa dengan kebutuhan tenaga kerja yang ada.

\section{DAFTAR PUSTAKA}

Alkin, M. C. (2011). Evaluation essentials: From A to Z. New York: The Guilford Press.

Badan Pusat Statistik (BPS). Data survey angkatan kerja bulan Agustus tahun 2012. Diambil pada tanggal 3 September 2013, dari pusdatinaker.balitfo.depnakertrans. go.id.

Depnakertrans RI. (2004). Keputusan Direktur Jenderal Pembinaan dan Penempatan Tenaga Kerja Dalam Negeri No. KEP131/DPPTKDN/XI/2004, tentang Petunjuk Teknis Bursa Kerja Khusus.

Dinas Pendidikan Provinsi Jawa Tengah. (2010). Pedoman pengelolaan bursa kerja khusus sekolah menengah kejuruan (SMK) Jawa Tengah. Semarang: Dinas Pendidikan Provinsi Jawa Tengah.

Engelland, B.T., Workman, L., \& Singh, M. (2000). Ensuring service quality for campus career services centers: A modified SERVQUAL scale. Journal of Marketing Education. 22. 236-245.

Ferguson. (2008). Encyclopedia of careers and vocational guidance. New York: Infobase Publishing.

Fitzpatrick, J. L., Sanders, J. R \& Worthen, B. R. (2004). Program evaluation: Alternative approaches and practical guidelines. New York: Pearson Education, Inc.

Heckhausen, J. \& Tomasik, J. M. (2002). Get an apprenticeship before school is out: How German adolescents adjust vocational aspirations when getting close to a developmental deadline. Journal of Vocational Behavior. 60. 199-219.

Istianyani, A. (2012). Upaya percepatan daya serap lulusan Fakultas Teknik melalui optimalisasi peran bursa kerja khusus UNJ sebagai mitra dari dunia usaha dan industri. Journal APTEKINDO. 16 (1) 143-147. 
Kaufman, R. \& Thomas, S. (1980). Evaluation without fear. New York: New ViewPoints.

Kerka, S. (Ed). (2006). Occupational skills training. Columbus: The Ohio State University.

Madaus, G. F., Scriven, M. S. \& Stufflebeam, D. L. (1986). Evaluation models: Viewpoints on educational and human services evaluation. Norwell: Kluwer Academic Publisher.

Mardapi, D. (2008). Teknik penyusunan instrumen tes dan nontes. Yogyakarta: Mitra Cendikia Offset.

OECD. (2010). Learning for job. Corrigenda: OECD publications.

Organisasi Perburuhan Internasional. (2007). Kajian tentang ketenagakerjaan kaum muda di Indonesia. Jakarta: Kantor Perburuhan Internasional.

Rivai, V., et.al. (2011). Performance apparsial. Jakarta: PT Raja Grafindo Persada.

Spaulding, D. T. (2008). Program evaluation in practice: Core concepts and example for discussion and analysis. San Francisco: Jossey-Bass.
Stufflebeam, D. L \& Shinkfield, A. J. (1984). Systematic evaluation: A self-instructional guide to theory and practice. Massachusetts: Kluwer Academic Publishers.

Sudira, P. (2012). Filosofi \& teori pendidikan vokasi dan kejuruan. Yogyakarta: Uny Press.

Talbot, C. (2010). Theories of performance: Organizational and service improvement in the public domain. New York: Oxford University Press.

US Fed News Service, Including US State News. (3 Maret 2008). Austria: Public employment service - record plus in job placement services. Diakses tanggal 20 September 2013 dari http://search.proquest.com/docview/469505048?account $\mathrm{id}=31324$.

Walter, E. (2005). Cambridge advance learner's dictionary. Cambridge: Cambridge University Press.

Wholey, J. S., Hatry, H. P. \& Newcomer, K. E. (Ed.). (2010). Handbook of practical program evaluation. San Francisco: Jossey-Bass. 